Received by $25 \%$

MAY 311990

\title{
HRTEM/AEM Study Of Trace Metal Behavior, Sheet Silicate Reactions, aNd Fluid/Solid Mass Balances IN PORPhyry COPPER Hydrothermal
} SYSTEMS

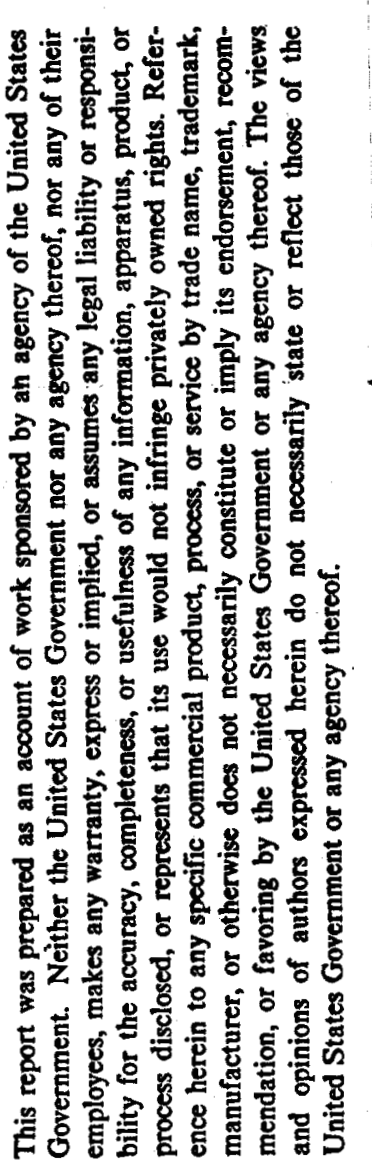

\author{
Progress Report \\ September 1, 1989 - August 31, 1990 \\ David R. Veblen and Eugene S. Iton \\ Department of Earth and Planetary Sciences \\ The Johns Hopkins University \\ Baltimore, Maryland 21218
}

April, 1989

Prepared for the U. S. Department of Energy

Agreement No. DE-FG02-89ER 14074

\section{NOTICE}

This report was prepared as an account of work sponsored by the United States Government. Neither the United States nor the Department of Energy, nor any of their contractors, subcontractors, or their employees, makes any warranty, express or implied, or assumes any legal liability or responsibility for the accuracy, completeness, or usefulness of any information, apparatus, product, or process disclosed or represents that its use would not infringe privately owned rights. 


\section{DISCLAIMER}

This report was prepared as an account of work sponsored by an agency of the United States Government. Neither the United States Government nor any agency Thereof, nor any of their employees, makes any warranty, express or implied, or assumes any legal liability or responsibility for the accuracy, completeness, or usefulness of any information, apparatus, product, or process disclosed, or represents that its use would not infringe privately owned rights. Reference herein to any specific commercial product, process, or service by trade name, trademark, manufacturer, or otherwise does not necessarily constitute or imply its endorsement, recommendation, or favoring by the United States Government or any agency thereof. The views and opinions of authors expressed herein do not necessarily state or reflect those of the United States Government or any agency thereof. 


\section{DISCLAIMER}

Portions of this document may be illegible in electronic image products. Images are produced from the best available original document. 


\section{Table of Contents}

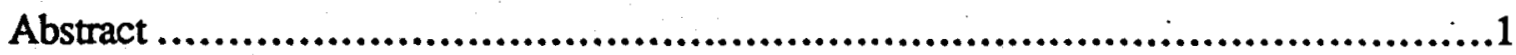

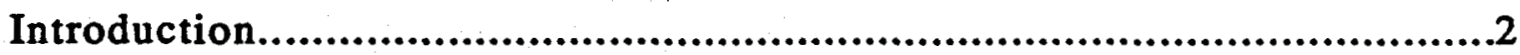

Experimental Methods and Sample Descriptions................................................4

Transmission Electron Microscopy ...............................................4

TEM Sample Preparation .........................................................5

Electron Microprobe Analysis....................................................6

Experimental Studies of Biotite/Cu-rich Fluid Interactions ..........................6

Descriptions of Natural Samples....................................................7

Porphyry copper deposits reported to have high-Cu silicates ................7

Cyprus Casa Grande (Lakeshore) deposit, Arizona ..........................7

Bingham Canyon deposit, Utah....................................................8

Research Progress ......................................................................9

Copper Porphyries Reported to have High-Cu Silicates ............................9

Cyprus Casa Grande Deposit..................................................................11

Experimentally Reacted Biotites................................................................ 19

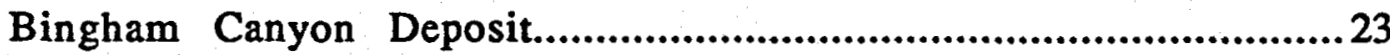

Research Plans for the Second Year......................................................25

Cyprus Casa Grande Studies.......................................................25

Experimental Studies ...............................................................26

Bingham Canyon Studies.......................................................22

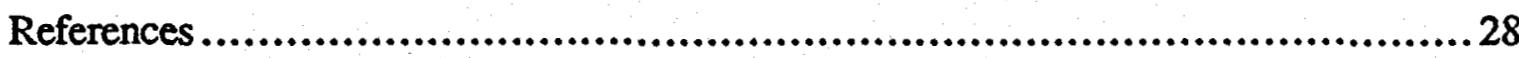

Appendix I: Ilton and Veblen (1983) ..................................................30 


\section{LIST OF TABLES}

Table 1. Samples from porphyry copper systems reported to have high-Cu silicates $\ldots . .10$

Table 2. Samples from the Cyprus Casa Grande (Lakeshore) deposit, Arizona .......... 12

Table 3. Samples from the Bingham Canyon deposit, Utah............................24

\section{LIST OF FIGURES}

Figure 1. Cyprus Casa Grande cross section........................................ 13

Figure 2. Cu-bearing goethite in Cyprus Casa Grande biotite........................... 15

Figure 3. Chrysocolla lamellae in Cyprus Casa Grande biotite.................................... 16

Figure 4. Cyprus Casa Grande biotite with numerous expanded interlayers ..............17

Figure 5a. $\mathrm{Cu}$ in experimentally reacted biotite, parallel to layers.........................20

Figure $5 b . \mathrm{Cu}$ in experimentally reacted biotite, normal to layers......................21

Figure 5c. Twinned $\mathrm{Cu}$ inclusion in experimentally reacted biotite ......................22 


\begin{abstract}
Transmission electron microscopy has been used to investigate $\mathrm{Cu}$ incorporation into silicates and alteration reactions in porphyry copper deposits. High $\mathrm{Cu}$ in biotites results from submicroscopic inclusions of native $\mathrm{Cu}$. The incorporation of $\mathrm{Cu}$ in low-temperature alteration lamellae suggests that Cu enrichment occurs during weathering, rather than during the hydrothermal event. Drill core from Cyprus Casa Grande, Arizona, shows systematic variation of $\mathrm{Cu}$ in sheet silicates as a function of depth in the weathering column.
\end{abstract}

To test the possibility that $\mathrm{Cu}$ is introduced during weathering, we reacted fresh biotite in a flow-through apparatus with $\mathrm{CuSO}_{4}$ solutions at $25^{\circ} \mathrm{C}$ and $1 \mathrm{~atm}$ in air. $\mathrm{Cu}$ inclusions formed that were indistinguishable from those occurring in natural porphyry copper deposits. Aqueous $\mathrm{Cu}$ liberated during weathering of $\mathrm{Cu}$ sulfides thus reacts with $\mathrm{Cu}$-poor biotite. These results indicate that biotite can be an important sink for base metals, immobilizing them under low-temperature conditions when metal-bearing fluids migrate through biotite-bearing rocks or soils.

Silicate alteration products and textures from Cyprus Casa Grande and Bingham Canyon, Utah, document the sequence and mechanisms of alteration reactions in the main-stage hydrothermal events, inferring the changes in hydrothermal fluid chemistry associated with silicate alteration. 


\section{INTRODUCTION}

Because they represent dead hydrothermal systems and are commonly deeply weathered, porphyry copper deposits provide a natural laboratory for understanding the geochemical behavior of trace and minor metals both in hydrothermal systems and in the low-temperature, near-surface environment. In addition, porphyry copper systems provide an opportunity to examine the silicate alteration reactions associated with hydrothermal activity. As a result, much effort has been expended in documenting the sequence and chemistry of these reactions, although most of it has been from an economic geology perspective (e.g., Beane and Titley, 1981).

The aims of the present project are to apply the powerful techniques of transmission electron microscopy (TEM), high-resolution TEM (HRTEM), and analytical electron microscopy (AEM) to understanding the geochemical processes in porphyry copper systems at the near-atomic scale. Our primary goals are (1) to characterize the structural state of anomalously high $\mathrm{Cu}$ in silicates, determine the timing and conditions of $\mathrm{Cu}$ enrichment in silicates such as biotite, and use these data to suggest how base metals are released and subsequently immobilized under hydrothermal or weathering conditions; and (2) to determine the submicroscopic, atomic-level reaction mechanisms responsible for silicate alteration in porphyry-copper hydrothermal systems, which will allow us to determine reaction stoichiometries and hence mass balances between minerals and hydrothermal fluid.

To achieve these aims, we are currently applying TEM methods to (1) natural samples from a number of porphyry copper deposits, in order to test the generality of our observations on Cu distributions; (2) large, systematic suites of well-documented samples from the Cyprus Casa Grande (formerly Lakeshore) and Bingham Canyon hydrothermal systems; and (3) the run products from a series of experiments we have begun to better 
understand how Fe-bearing silicates react with $\mathrm{Cu}$-bearing fluids. In this Progress Report, we outline the successes we have had to date in these efforts. Note that the project funding started September 1, 1989, so that this report covers only about seven months of work, rather than a full year. During this time, the PI devoted 1/12 of his effort to the project, and he plans to devote a similar fraction of his time to this research for the remainder of the budget period. 


\section{EXPERIMENTAL METHODS AND SAMPLE DESCRIPTIONS}

\section{Transmission Electron Microscopy}

Electron microscopy was performed in the Johns Hopkins high-resolution transmission electron microscopy laboratory, which is housed in the Department of Earth and Planetary Sciences, as described in part by Veblen and Bish (1988) and Livi and Veblen (1987). Identification, orientation, and chemical information on the various phases present in our samples were determined using the full range of capabilities of the TEM, including imaging modes, selected-area electron diffraction (SAED), convergent-beam electron diffraction (CBED), and X-ray emission AEM. The primary instrument in this laboratory is a Philips 420ST (SuperTwin) electron microscope, which has a spherical aberration coefficient $C_{s}=1.2 \mathrm{~mm}$ and chromatic aberration coefficient $C_{c}=1.2 \mathrm{~mm}$. Experiments were performed at $120 \mathrm{keV}$. For HRTEM experiments, the objective aperture size was matched to the point-to-point resolution of the microscope $(0.30 \mathrm{~nm})$; the line resolution of the instrument is $0.14 \mathrm{~nm}$. SAED experiments were performed with a resolution down to approximately $0.3 \mu \mathrm{m}$, while the CBED resolution is about $2 \mathrm{~nm}$. Analytical resolution ( $90 \%$ column) varies as a function of the specimen geometry and material analyzed but is a minimum of approximately $20 \mathrm{~nm}$ under ideal circumstances. Inclusions even smaller than $20 \mathrm{~nm}$ can be characterized chemically by collection of diluted spectra, followed by subtraction of the matrix analysis.

$\mathrm{X}$-ray spectra were collected with an EDAX lithium-drifted, solid-state, energy-dispersive detector inclined $20^{\circ}$ to the horizontal. The detector signal was processed with a Princeton Gamma-Tech System 4 X-ray analyzer. The samples were analyzed in beryllium-cup low-background double-tilt specimen holders at tilts between $10^{\circ}$ and $25^{\circ}$ toward the detector, giving effective take-off angles between $30^{\circ}$ and $45^{\circ}$. Analyses were obtained in conventional TEM mode, with spot sizes ranging from approximately 20 to 100 
$\mathrm{nm}$ in diameter. For quantitative analysis, X-ray background was removed from spectra by scaling and subtracting a floating-reference background spectrum generated from $\mathrm{MnCO}_{3}$ (with the characteristic Mn peaks removed), using the TwIST algorithm of Aden and Buseck (1979). Characteristic X-ray peak intensities were obtained by a FRAME-C type Gaussian decomposition (Myklebust et al., 1978). Atomic weight percentages were calculated by the Cliff-Lorimer thin-film ratio method (Cliff and Lorimer, 1975), assuming no absorption of fluorescence effects. The $k$ factors with respect to $\mathrm{Si}$ for $\mathrm{Na}, \mathrm{Mg}, \mathrm{Al}, \mathrm{K}$, $\mathrm{Ca}, \mathrm{Mn}$, and $\mathrm{Fe}$ were empirically derived from ion-milled silicate standards listed by Livi (1988). The $k$ factors for other elements were calculated by the method of Zaluzek (1984).

Based on repeated analyses of homogeneous standard silicates, the standard deviations of our X-ray intensity ratios are $\sigma \leq 2 \%$ or less for major elements. Likewise, the standard deviations of $k$ factors derived from numerous analyses of several standards for each element are $2 \%$ or better. Although the precision of analyses obtained under optimum conditions is on the order of $2 \%$, the accuracy of our analyses for most major elements is estimated to be on the order of $5 \%$ relative to the amount present, owing to the uncertainty in $k$ values, counting statistics of the analysis, and other factors, such as variations in specimen geometry. For $\mathrm{Na}$ and $\mathrm{K}$, errors may be higher, due to alkali loss from the analysis spot and to relatively poor sensitivity of the $\mathrm{Si} / \mathrm{Li}$ detector for $\mathrm{Na}$. The detection limits for most elements are 0.1-0.2 wt \%. Most important for this study, we estimate the detection limit for $\mathrm{Cu}$ to be approximately $0.1 \mathrm{wt} \%(1000 \mathrm{ppm})$.

\section{TEM Sample Preparation}

Thin samples for transmission electron microscopy were prepared by two primary methods. Most were prepared by argon ion milling of fragments extracted from petrographic thin sections that had been made with a thermoplastic cement (Aremco Crystalbond 509). These specimens were lightly coated with amorphous carbon to render 
them conductive in the electron beam. Observations were made at the thin edges of these ion-milled specimens that occur around perforations in the section. This specimen preparation method allows observation on biotite crystals to be made with the electron beam parallel to the 2:1 layers of the structure. Ag grids were used throughout the study, to preclude analytical interference from $\mathrm{Cu}$, the most common grid material for TEM studies.

For observations on biotite with the electron beam normal to the structural layers, an alternative preparation method was used. Cleaved sheets of the mica were placed between two pieces of cellophane tape and pulled apart. This process was repeated until the cleavage fragments were extremely thin (less than $0.1 \mu \mathrm{m}$ thick). Grids were then epoxied to the biotite. After curing, the tape was pulled off with a final layer of biotite, leaving a thin layer of uncontaminated biotite on the grid.

\section{Electron Microprobe Analysis}

Electron microprobe analyses, including digital X-ray dot maps, were obtained on many of the biotites prior to preparation for electron microscopy. Analyses were performed according to standard procedures with either a JEOL 8600 SuperProbe or an ARL SEMQ.

\section{Experimental Studies of Biotite/Cu-rich Fluid Interactions}

The experiments on the reaction of biotite with $\mathrm{Cu}$-bearing aqueous fluids were performed to test the hypothesis that $\mathrm{Cu}$ inclusions can form under low-temperature (i.e., supergene or weathering) conditions. Samples of homogeneous Bancroft, Ontario, biotite (checked for homogeneity, absence of $\mathrm{Cu}$ inclusions, and $\mathrm{Cu}$ concentrations using TEM and electron microprobe) were cleaved into books approximately $5 \mathrm{~mm}$ across and $2 \mathrm{~mm}$ thick. In our initial experiments, reported here, these pieces were placed in a 
non-recirculating flow-through reactor and allowed to react with 12 wt \% $\mathrm{CuSO}_{4}$ solution in water for 13 days at $25^{\circ} \mathrm{C}, 1 \mathrm{~atm}$ pressure, and $\mathrm{pH}=3$. The samples were then removed from the reactor and washed with ultrapure water. Other experiments were performed by suspending the biotite books in a teflon mesh bag in a flow-through water bath with 1 wt \% $\mathrm{CuSO}_{4}, \mathrm{pH}=4$, at $25^{\circ} \mathrm{C}$ and $1 \mathrm{~atm}$. TEM specimens were prepared as described above, and observations were made in the same way as those on the natural samples. Results are described below in the section on progress.

\section{Descriptions of Natural Samples}

\section{Porphyry copper deposits reported to have high-Cu silicates. Ostensibly} unweathered samples (i.e., no supergene enrichment) were obtained from several porphyry copper deposits for which $\mathrm{Cu}$ analyses have been reported from biotite and other minerals. These samples (listed in Table 1) were obtained directly from the authors of the papers reporting the $\mathrm{Cu}$ analyses, so that we could correlate our results directly with the previous work. The deposits include the Chikora tonalite porphyry of the Koloula igneous complex, Solomon Islands, and the porphyry (Oxhide) phase of the Schultze Granite, Globe-Miami district, Arizona; Cu analyses for these rocks were published by Hendry et al. (1981, 1985), and our preliminary results from these two localities were reported by Ilton and

Veblen (1988). The other samples are from the Christmas Mine, Arizona; the Pinto Valley granodiorite from the Globe-Miami district; and the Kolokemau tonalite, Solomon Islands (also from the Koloula igneous complex).

\section{Cyprus Casa Grande (Lakeshore) deposit, Arizona. Relatively high-Cu biotites} were reported from this deposit by Cook (1988), who noted Cu contents as high as 4 wt $\%$ (when taken as $\mathrm{CuO}$ ). The Cyprus Casa Grande deposit is ideal for understanding the geochemical role of $\mathrm{Cu}$ and for determining the timing of $\mathrm{Cu}$ enrichment in silicates, since there is complete drill core extending from the highly weathered goethite zone down to the 
unweathered, but hydrothermally altered, protore. Moreover, large primary biotite phenocrysts were preserved throughout the entire weathering column. We were able to obtain an excellent suite of samples representing all major zones (kindly provided by $S$. Cook). The Cyprus Casa Grande specimens we have studied to date are listed in Table 2.

Bingham Canyon deposit. Utah. This is one of the largest ancient hydrothermal systems in North America, and, due to its importance as a copper producer, it has been studied extensively in terms of its ore geochemistry, petrology, and stable isotope distributions (e.g., Bowman et al., 1987). We have obtained an extensive suite of well-documented Bingham samples from J. R. Bowman (University of Utah). Samples on which we have made initial progress are listed in Table 3. 


\section{ReSEARCh Progress \\ (SEPTEMBER 1, 1989, TO MARCH 31, 1990)}

Our progress to date is divided into four sections: (1) observations on rocks from a number of porphyry copper hydrothermal systems that have been reported as having high-Cu silicates, (2) observations on drill core from the Cyprus Casa Grande deposit, (3) observations on experimentally reacted biotites, and (4) observations on the Bingham Canyon suite.

\section{Copper Porphyries Reported to have High-Cu Silicates}

As indicated in Table 1, we examined primary (as opposed to hydrothermal) biotites from five different intrusions in this part of the study. All of the samples of high-Cu biotites contained inclusions of native Cu metal (but see section on Cyprus Casa Grande, where mode of $\mathrm{Cu}$ occurrence is more complex). Even in biotites with $\mathrm{Cu}$ contents as low as $300 \mathrm{ppm}$ (by ion probe analysis), native $\mathrm{Cu}$ inclusions were noted. Thus, even when $\mathrm{Cu}$ is present in trace amounts, one cannot assume that all the $\mathrm{Cu}$ is in solid solution in biotite. Furthermore, in none of these samples could $\mathrm{Cu}$ be detected in biotite outside regions with $\mathrm{Cu}$ inclusions, underscoring the conclusion that it is the inclusion distributions that control the overall $\mathrm{Cu}$ distributions. Cu in chlorites is commonly found associated with altered zones (e.g., hydrobiotite lamellae), as noted by IIton and Veblen (1988). Finally, Cu inclusions were found in hornblende, indicating that biotite is not the only mineral that may incorporate trace metals as distinct inclusions, as opposed to being in solid solution.

This part of the study thus demonstrates the generality of our earlier observations. The occurrence of $\mathrm{Cu}$ in biotites as inclusions is not an isolated, unusual phenomenon, but rather appears to be a common means of incorporation of this trace/minor metal in sheet silicates. 
Table 1. Samples from porphyry copper systems reported to have high-Cu silicates

Location/Formation Sample Cu in primary observation

Christmas Mine area, $\mathrm{AZ}$

$\begin{array}{llll}\begin{array}{l}\text { Biotite granodiorite } \\ \text { porphyry }\end{array} & \begin{array}{l}\text { C-4 } \\ \text { (KC-20-73) }\end{array} & 30-380 \mathrm{ppm}^{1} & \begin{array}{l}\text { Cu inclusions observed } \\ \text { in primary biotite }\end{array}\end{array}$

Globe-Miami district, AZ

$\begin{array}{llll}\begin{array}{l}\text { Porphyry phase } \\ \text { (Oxhide) }\end{array} & \text { OX } & 20-1100 \mathrm{ppm}^{1} & \begin{array}{l}\text { Cu inclusions observed } \\ \text { in primary biotite }\end{array} \\ \begin{array}{l}\text { Granodiorite } \\ \text { (Pinto Valley) }\end{array} & \text { PV-1 } & 24-300 \mathrm{ppm}^{1} & \begin{array}{l}\text { Cu inclusions observed } \\ \text { in primary biotite }\end{array}\end{array}$

Koloula Igneous Complex, Solomon Islands

Chikora tonalite
porphyry

$52477 \quad$ No analyses for this rock, but $600-900 \mathrm{ppm}$ in hydrothermal biotite and $0.6-2 \% \mathrm{Cu}$ in chlorite reported for this intrusion ${ }^{2}$ Kolokemau A-524 300-5000 $\mathrm{ppm}^{2}$

Cu inclusions observed in primary biotite tonalite

Cu inclusions observed in primary biotite

1 Hendry et al. (1985).

2 Hendry et al. (1981). 


\section{Cyprus Casa Grande Deposit}

We were very fortunate to obtain a systematic suite of samples from the Cyprus Casa Grande (formerly Lakeshore) deposit, Arizona (Cook, 1988). This suite consists primarily of drill core (see Figure 1) that extends through the entire sequence of supergene zones into the completely unweathered protore (a composite granodiorite stock). Core 3F extends from surface to protore; core $400-6$ is reverse, drilled up from protore; LS-13 is a hand sample from the shaft near the origin of core 400-6. Because it spans all the alteration zones, this is an ideal set of samples for exploring the crystal chemistry of the layer silicates and the geochemical behavior of minor or trace base metals (i.e., $\mathrm{Cu}$ ) during both hypogene (hydrothermal) and supergene (low-temperature, weathering) alteration.

To date, we have made at least preliminary observations on seven Cyprus Casa Grande samples, which are summarized in Table 2 . We will report these observations at the Annual Meeting of the Geological Society of America this fall (Ilton and Veblen, 1990). Note that all samples that experienced supergene alteration contain detectable $\mathrm{Cu}$ in biotite (by microprobe), while the biotite and chlorite of the unweathered protore does not (other than vein and disseminated chalcopyrite observable with the petrographic microscope). Furthermore, native $\mathrm{Cu}$ inclusions are observed only in biotites from oxidized ore. Comparison of the Cyprus Casa Grande samples to samples from other deposits leads us to the general conclusion that $\mathrm{Cu}$ in sheet silicates from porphyry copper systems is introduced during weathering, not during the magmatic stage or the hydrothermal stage of alteration. This surprising conclusion is counter to the prevailing wisdom that high-Cu silicates can be related to the main-stage hydrothermal activity. It suggests that even at low temperatures, $\mathrm{Cu}$-bearing fluids are able to react with sheet silicates. This raises interesting possibilities concerning the demobilization of metals in relatively low-temperature, weathering zones (e.g., in soils), with potential applications and implications for the 
Table 2. Samples from the Cyprus Casa Grande (Lakeshore) deposit, Arizona

\section{Core/Depth1 Zone Observations}

3F/479' Goethite Cu inclusion-rich zones in biotite. Also abundant Fe-rich inclusion zones (goethite); these inclusions show low but measurable $\mathrm{Cu}(0.2 \% \leq \mathrm{Cu} \leq 1 \%)$. Expanded interlayers in biotite most abundant in inclusion zones. Regions with expanded interlayers but no inclusions may show low Cu.

3F/558 Goethite Cu inclusions not yet observed. Abundant $\mathrm{Fe}$-rich inclusions and expanded interlayers; detectable Cu observed in goethite inclusions and in regions with numerous expanded interlayers.

$3 F / 613^{\prime}$

$3 \mathrm{~F} / 631^{\prime}$

Chrysocolla

Chrysocolla
Biotite fresher than in goethite zone. Infrequent regions with expanded interlayers and detectable $\mathrm{Cu}$.

\section{Same as 3F/613', except also observed infrequent $\mathrm{Cu}$ inclusions}

in biotite. Frequent chrysocolla inclusions ( $\approx 10-500 \mathrm{~nm}$ thick) in biotite have forced open the interlayers during precipitation. Abundant $\mathrm{Cu}$-rich (Cu or oxide) inclusions in chrysocolla. No $\mathrm{Cu}$ detected in areas without chrysocolla, native $\mathrm{Cu}$ inclusions, or expanded interlayers.

400-6/130 CupriteNative $\mathrm{Cu}$

Numerous $\mathrm{Cu}$ inclusions and expanded interlayers. Areas of "fresh" biotite with no detectable Cu. Regions with expanded interlayers contain detectable Cu. Biotite less altered than in goethite zone.

$3 F / 883^{\prime}$

Unweathered protore

Chalcopyrite in veinlets and some disseminated in biotite. $\mathrm{Cu}$ at or below detection limit of electron microprobe in both biotite and chlorite ( $\leq 100 \mathrm{ppm})$. In TEM, no detectable $\mathrm{Cu}$. No Cu or other inclusions in biotite, chlorite, or mixed-layer biotite/chlorite. Expanded interlayers rare or absent (biotite is fresh relative to other zones).

LS-13

Unweathered protore fresh and inclusion-free.

1 All samples are from Cook (1988). 


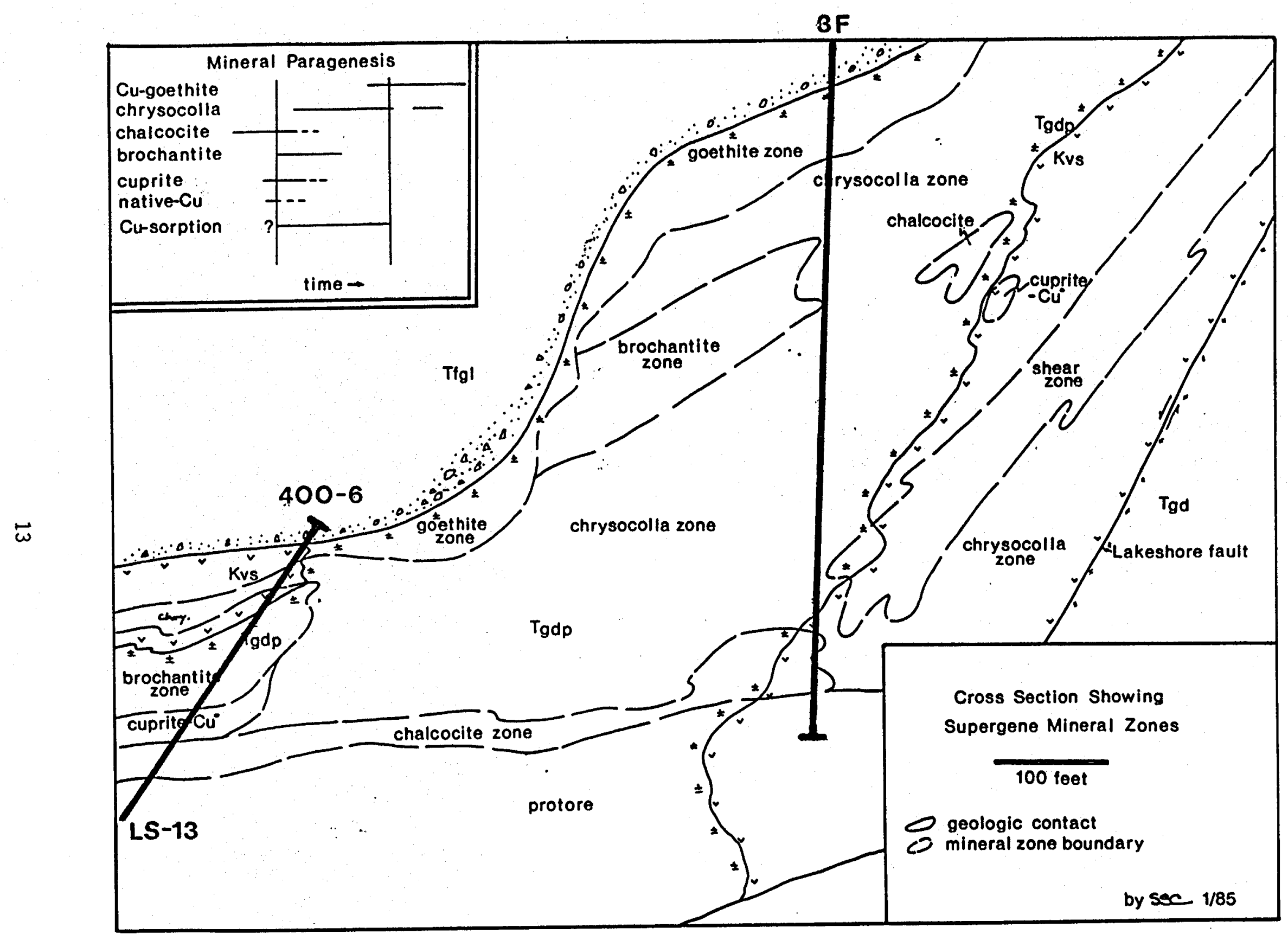


isolation of metal-bearing waste. The implications for the genesis of $\mathrm{Cu}$ ore deposits are also profound, since Cu-bearing silicates have been suggested as indicators for exploration and have been called upon as the ultimate sources of $\mathrm{Cu}$ (e.g., see references 1-12 in Ilton and Veblen, 1988). The realization that the high-Cu silicates are a later, low-temperature phenomenon also obviates the need to explain why the Cu typically is present in the sheet silicates as native $\mathrm{Cu}$, rather than as a sulfide (the predominant $\mathrm{Cu}$ minerals of the hydrothermal stage are chalcopyrite and other sulfides).

The Cyprus Casa Grande samples also demonstrate that the mode of incorporation of $\mathrm{Cu}$ in biotite can be more complicated than we (or anyone else) had thought. Finding that most of the $\mathrm{Cu}$ in biotites with anomalous $\mathrm{Cu}$ is present as inclusions of native $\mathrm{Cu}$ was surprising enough (see commentary by Titley, 1988). Although the details can be read from Table 2, we note here that $\mathrm{Cu}$ is also associated with (1) goethite inclusions in the goethite zone (Figure 2), where it either may be in solid solution proxying for Fe or may be present as adsorbed layers; (2) submicroscopic chrysocolla lamellae that have forced apart the biotite layers in the chrysocolla zone, where the $\mathrm{Cu}$ is largely held in a distinct phase, either native $\mathrm{Cu}$ or an oxide within the chrysocolla (Figure 3); and (3) regions of biotite with numerous expanded interlayers--probably vermiculitized layers--but no observable inclusions (Figure 4), thus suggesting that it is held in solid solution as interlayer complexes.

These various modes of $\mathrm{Cu}$ incorporation, coupled with the fact that native $\mathrm{Cu}$ and goethite inclusions commonly lie on expanded (vermiculitized) interlayers, suggest that $\mathrm{Cu}$ incorporation takes place by a two-step process. First, the biotite structure is partially vermiculitized, a common weathering reaction (Banfield and Eggleton, 1988), and Cu is incorporated in the interlayer regions, where it may proxy for potassium. One possibility is:

$$
\mathrm{Cu}^{+}(\mathrm{aq})+\mathrm{K}^{+}(\text {interlayer }) \rightarrow \mathrm{Cu}^{+}(\text {interlayer })+\mathrm{K}^{+}(\mathrm{aq})
$$


Figure 2. Cypress Casa Grande biotite showing a lamella and inclusions of $\mathrm{Cu}$-bearing goethite $(G)$. Layers in the biotite with lighter contrast are expanded interlayers.

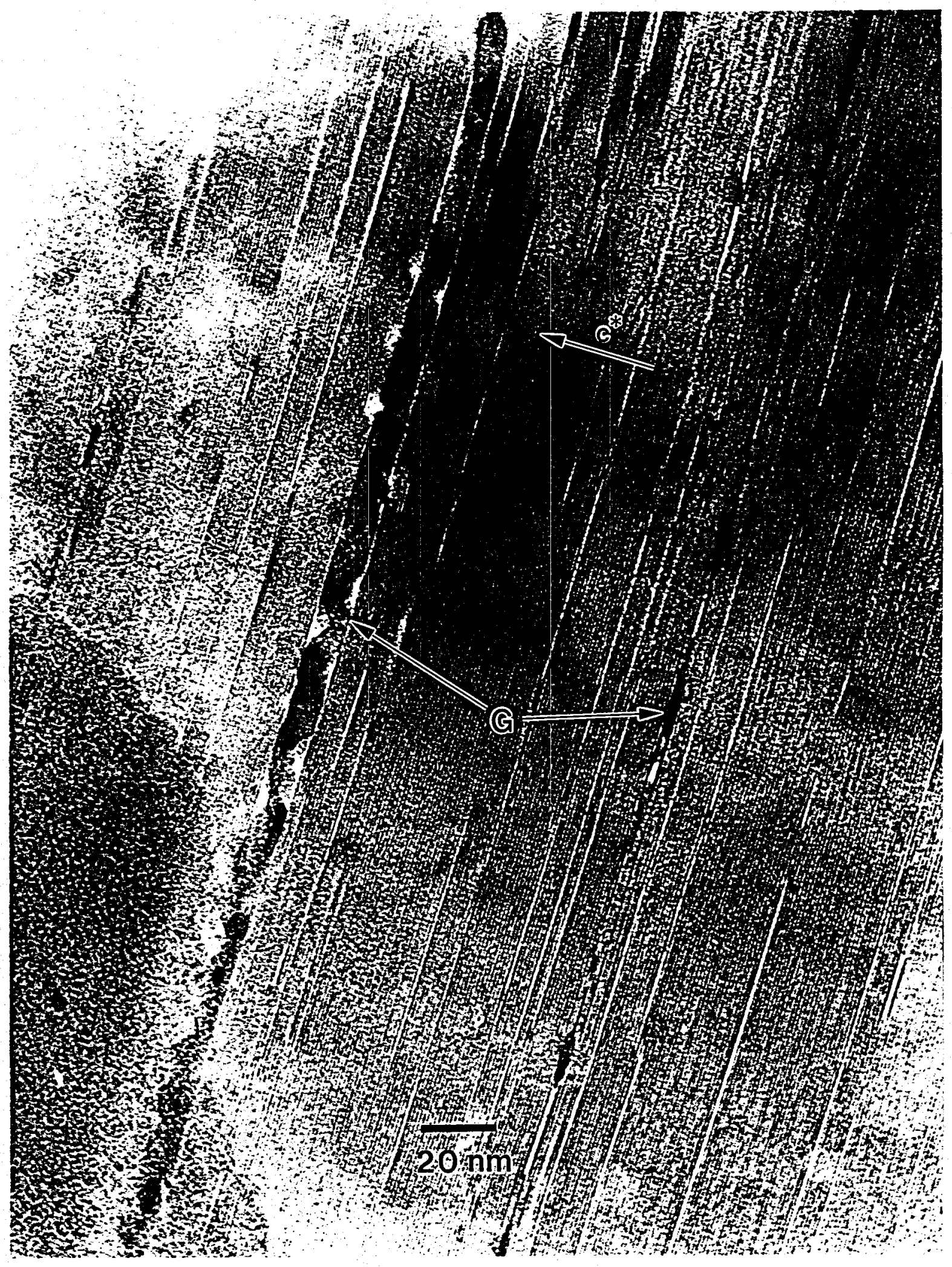


Figure 3. Lamellae of chrysocolla (C) intergrown in Cyprus Casa Grande biotite (B). Small, dark inclusions in the chrysocolla are native $\mathrm{Cu}$ or $\mathrm{Cu}$ oxide.

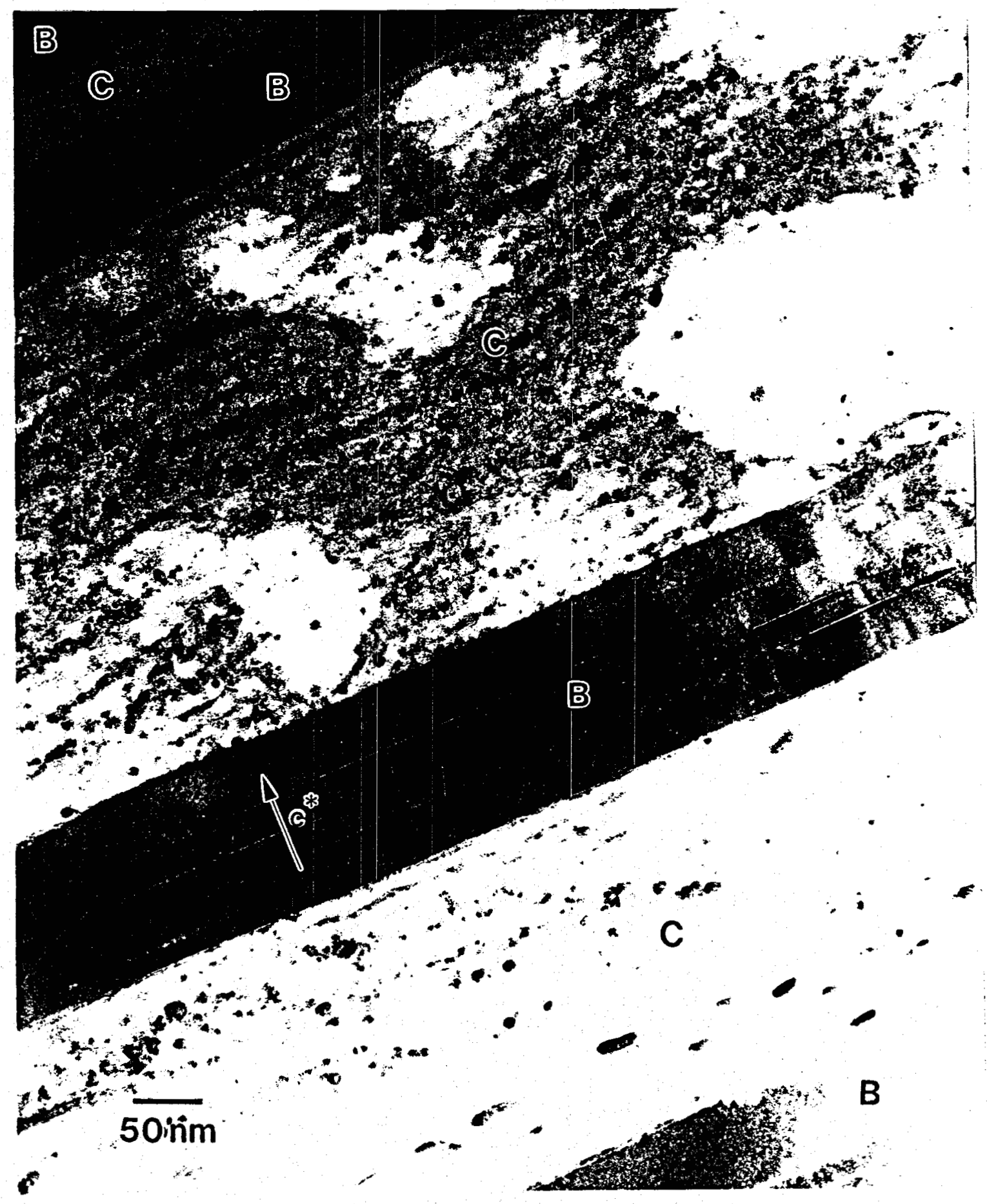


Figure 4. Region of Cyprus Casa Grande biotite showing numerous expanded (presumably vermiculitized) interlayers (layers with lighter contrast). Such regions commonly show low-level but detectable Cu.

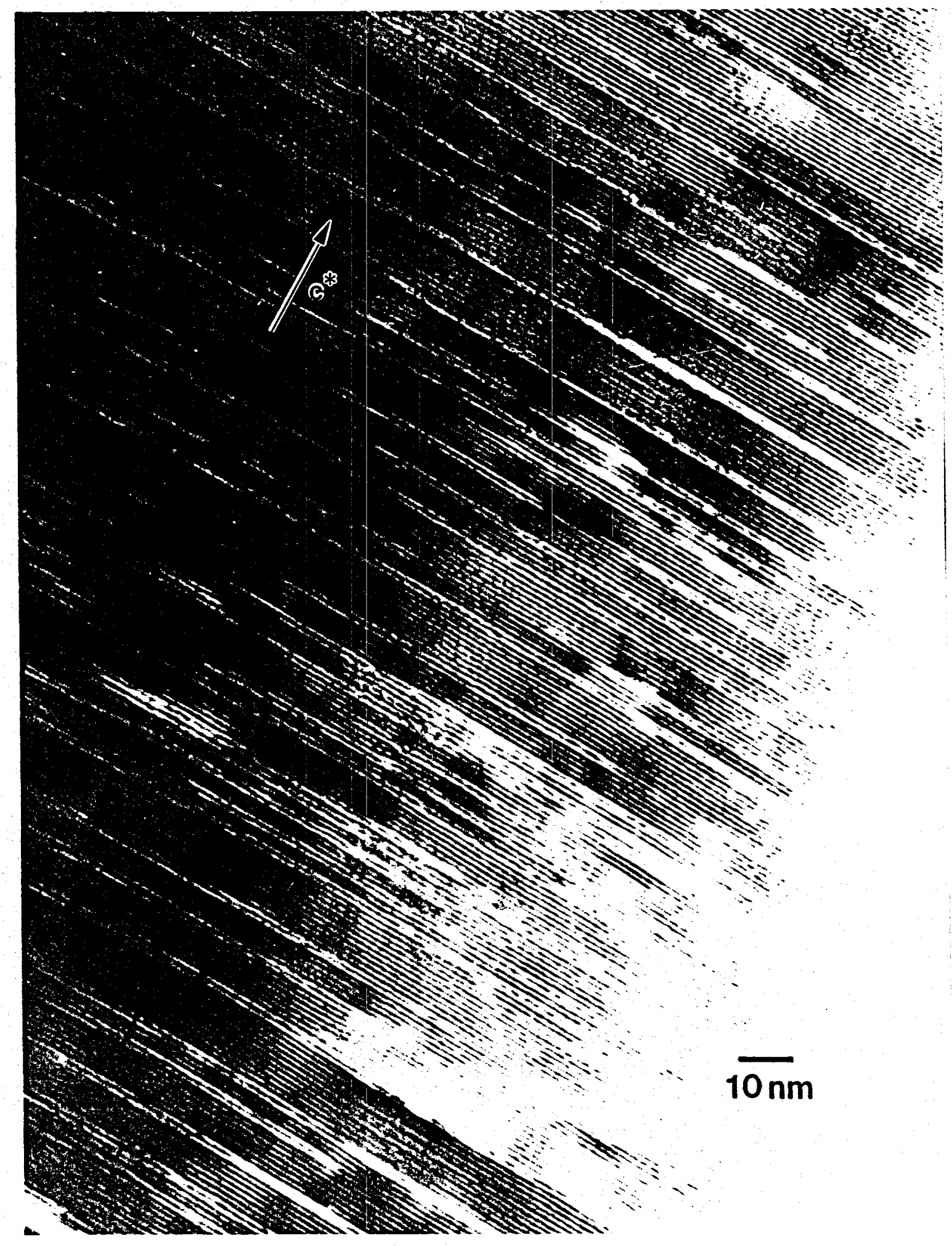


The fact that we observe this state indicates that it is not merely transient but may persist for long periods. The second step, that of inclusions formation, requires reduction of the $\mathrm{Cu}$ to form $\mathrm{Cu}$ metal. This may take place via a redox reaction involving the octahedrally-coordinated Fe:

$$
\mathrm{Cu}+(\text { interlayer })+\mathrm{Fe}^{2+}(\mathrm{oct}) \rightarrow \mathrm{Cu} \text { (inclusion) }+\mathrm{Fe}^{3+}(\mathrm{oct}) .
$$

This second-stage reaction may account for our observation that $\mathrm{Cu}$ metal inclusions are rare or absent in regions of a biotite crystal with abundant goethite inclusions: in the highly oxidized regions with abundant goethite, the redox potential of the biotite may have been too exhausted to reduce the $\mathrm{Cu}$ interlayer complex to metallic $\mathrm{Cu}$. This possibility should be experimentally confirmable. 


\section{Experimentally Reacted Biotites}

We must confess to being surprised that anomalous $\mathrm{Cu}$ in biotites and chlorites appears to be introduced during low-temperature alteration, rather than the hydrothermal event. However, that conclusion appears to be inescapable, at least for the Cyprus Casa Grande porphyry copper system described in the last section. In order to confirm that biotite can react with $\mathrm{Cu}$-bearing solutions under weathering conditions to produce the features we observe in natural samples, we undertook the experiments described in the section Experimental Methods.... All of these experiments essentially involved reacting macrocrystalline biotite with $\mathrm{CuSO}_{4}$ solutions at $25^{\circ} \mathrm{C}$ and atmospheric pressure.

Following the experiments, we prepared the reacted biotite as described for TEM experiments. We found that reaction with the room-temperature $\mathrm{CuSO}_{4}$ solutions did, indeed, occur, producing textures and $\mathrm{Cu}$ distributions that are indistinguishable from those observed in natural biotites with anomalous $\mathrm{Cu}$ (Figure 5). (For comparison, see the figures of Itton and Veblen, 1988, reprint attached as Appendix I.) For example, inclusions of metallic $\mathrm{Cu}$ formed in the interlayer regions near the boundaries of the biotite crystals, commonly associated with expanded interlayers. In the 13-day experiment with $12 \mathrm{wt} \% \mathrm{Cu}, \mathrm{pH}=3$, the zone of alteration penetrated approximately $200 \mu \mathrm{m}$ in from the edge of the crystals. Figure 5 a shows $\mathrm{Cu}$ crystallites formed in an altered zone from this experiment; Figure 5b shows the large population of Cu crystals observed with the electron beam normal to the biotite layers; and Figure $5 \mathrm{c}$ shows a close-up of a single twinned $\mathrm{Cu}$ crystal, similar to those found in the natural $\mathrm{Cu}$-rich biotites.

It is thus clear that $\mathrm{Cu}$-rich solutions can react with ordinary biotite under ambient conditions and on short time scales to form $\mathrm{Cu}$-enriched sheet silicate. As noted above, this may have important consequences for the immobilization of trace metals in ground waters, as well as for interpretations regarding the evolution of porphyry $\mathrm{Cu}$ hydrothermal systems and ore deposits. It appears that weathering of primary $\mathrm{Cu}$ sulfides produces 
Figure 5a. Experimentally reacted biotite (viewed parallel to the layers) showing regions with abundant expanded interlayers and dark inclusions of metallic $\mathrm{Cu}$.

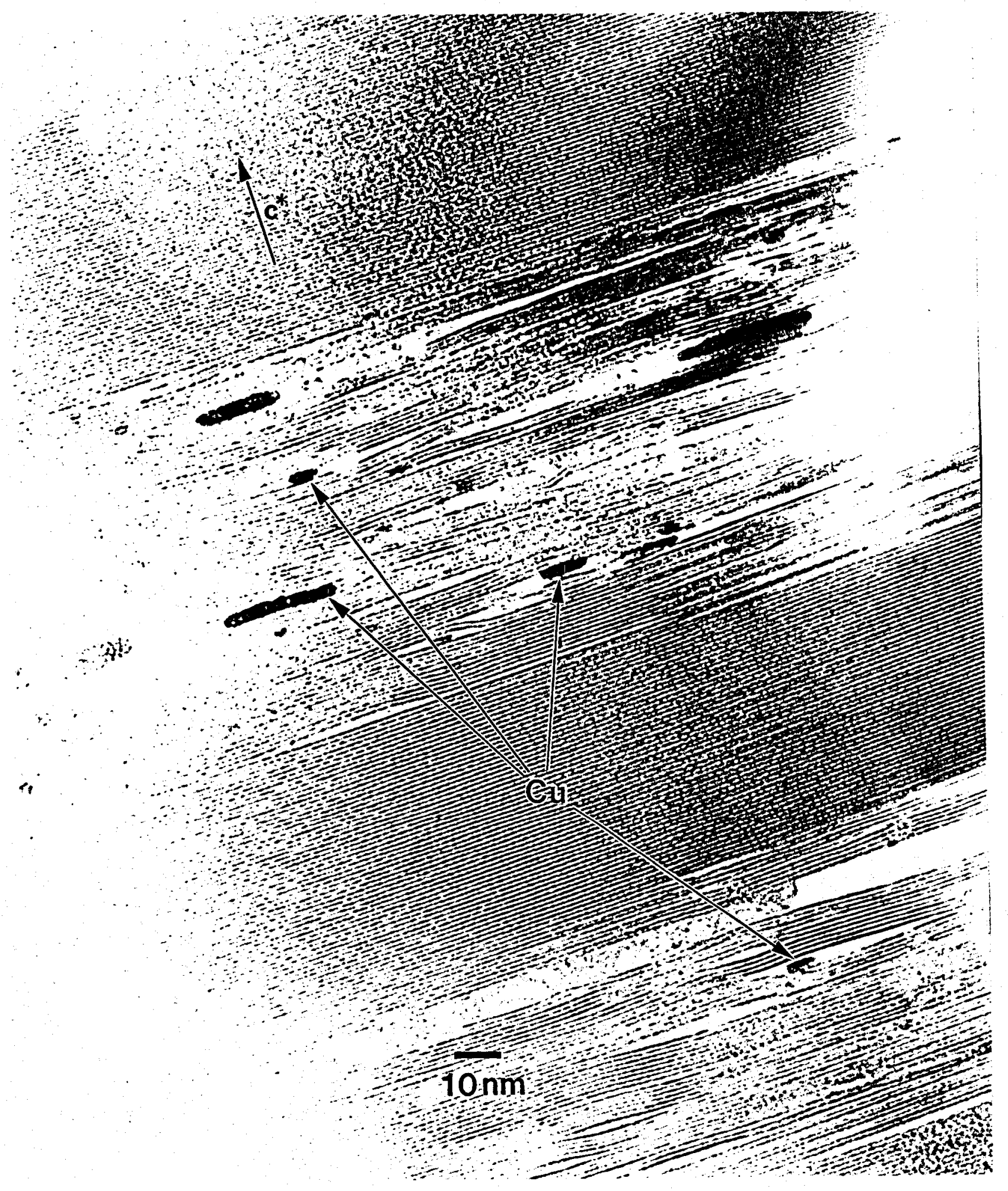


Figure $5 \mathrm{~b}$. Experimentally reacted biotite (viewed normal to the layers) showing numerous dark inclusions of metallic $\mathrm{Cu}$.

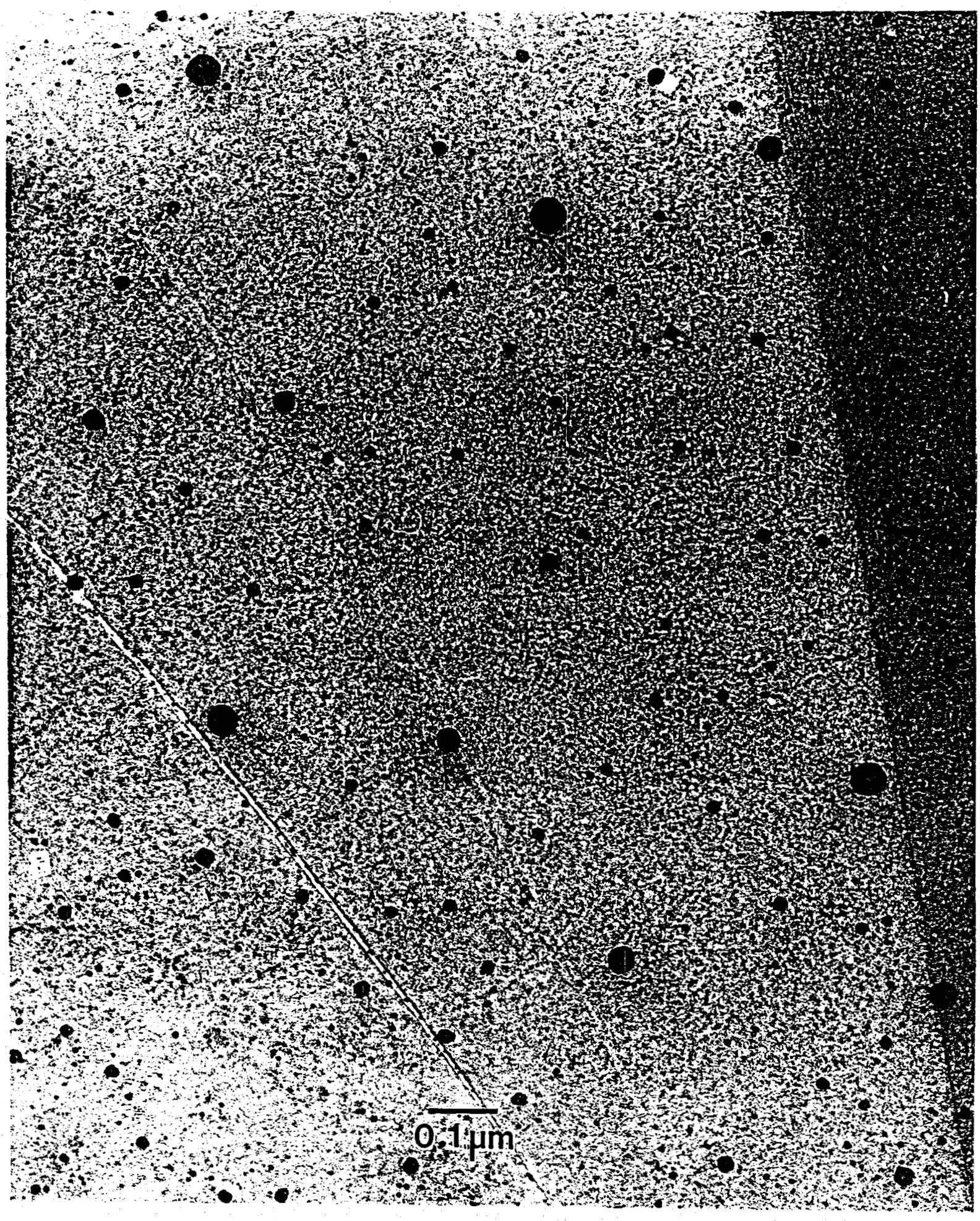


Figure 5c. Enlarged view of an inclusion such as those in Figure 5b, showing that some of the inclusions are twinned, just as in the natural samples.

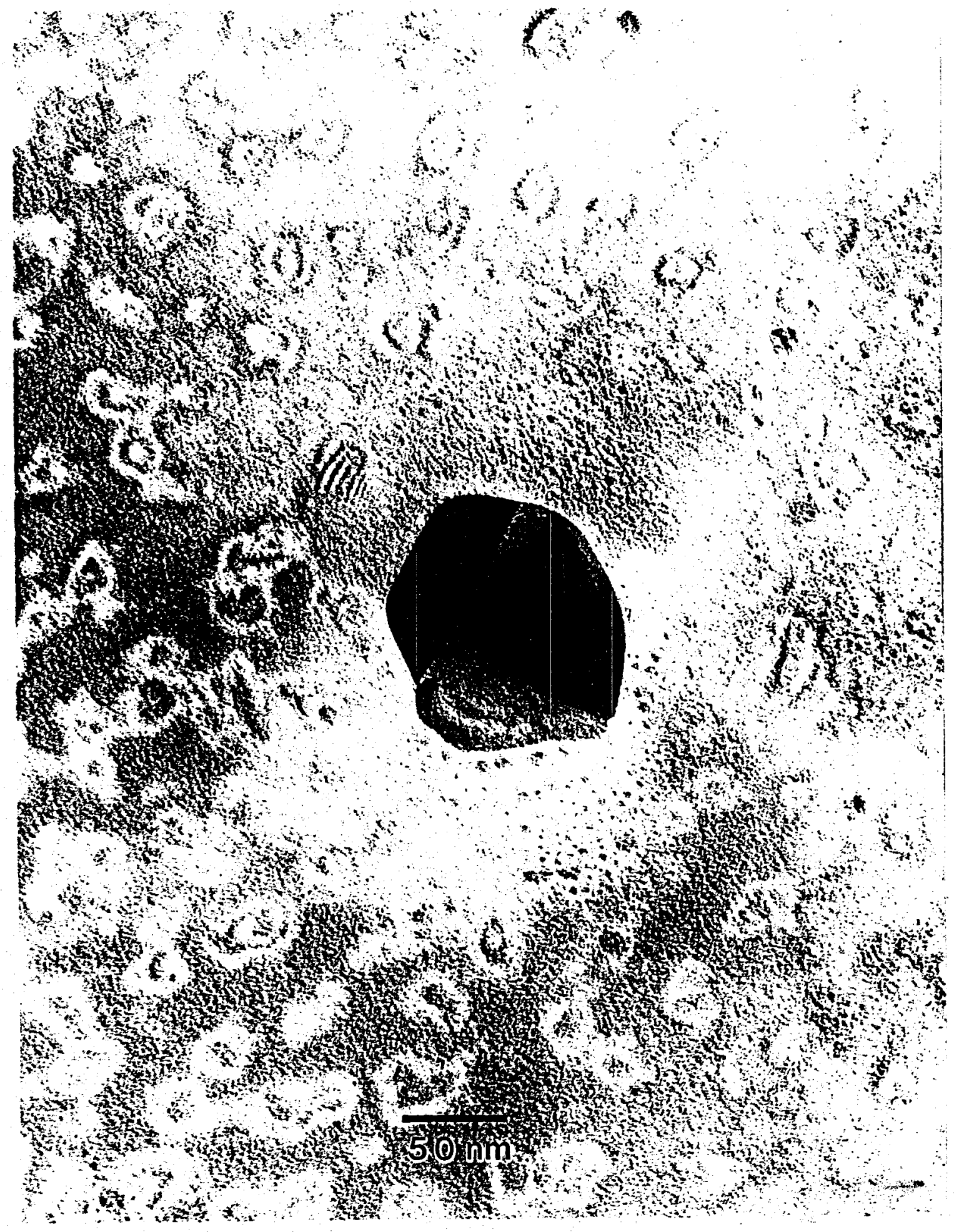


aqueous $\mathrm{Cu}$ and sulfate, and these solutions subsequently react with the sheet silicates in the rock, immobilizing the $\mathrm{Cu}$ by incorporation into the silicate. Although this is a likely chemical scenario for Cu enrichment of sheet silicates, it is also clear that additional experiments will prove useful for elucidating the exact chemistry of this type of reaction and the range of conditions over which such reactions can take place. Our initial results will be reported at the Annual Meeting of the Geological Society of America this fall (Earley et al., 1990).

\section{Bingham Canyon Deposit}

Although we have obtained an excellent suite of Bingham Canyon samples from J. R. Bowman and have begun our TEM work on these materials (Table 3), we do not yet have enough data to draw definitive conclusions about the geochemical behavior of metals during the various alteration events at this locality. We have observed the same types of alteration involving pyroxenes, amphiboles, biotite, chlorite, and feldspars that have been noted for other porphyry copper systems (e.g., Page and Wenk, 1979; the Cyprus Casa Grande rocks discussed above). As noted in the next section, we plan to continue our work on the Bingham Canyon suite during the second year of this project. Since this suite has been examined in detail using stable isotopic and standard petrologic techniques

(Bowman et al., 1987), we hope to be able to correlate our submicroscopic results with the larger-scale observations. 
Table 3. Samples from the Bingham Canyon deposit, Utah

\section{Sample 1 Alteration Zone Observations}

$225 \quad$ Monzonite

704-4 Propylitic zone
Relatively unaltered still shows some reaction, including hornblende rims around augite with sharp boundary (no intermediate phase), pigeonite exsolution from augite (probably high-T reaction), minor chain-width disorder in augite, and topotactic alteration of augite to biotite having a high degree of stacking disorder.
679-3 Propylitic zone
619-13-17 Potassic zone
679-3
Propylitic zone abundant. Preliminary observations only.
Augite completely altered to amphibole (actinolite), which exhibits chain-width disorder and polysynthetic twinning.
Pyrite veins cut actinolite crystals, but no extremely fine-grained sulfide inclusions. Biotite occurs with ordered $1 M$ polytype, virtually complete stacking disorder, and regions of longer-range polytypic order. Biotite has been partially replace by chlorite, forming intergrown lamellae of biotite and chlorite, but not intimately mixed-layer silicate. Chlorite exhibits major stacking disorder.

Pigeonite exsolution in augite, but pyroxene still relatively

1 All samples from Bowman et al. (1987). 


\section{Research Plans for THE SECOND YeAR (SEPTEMBER 1, 1990, TO AUGUST 31, 1991)}

From the progress report above, it is clear that we have made substantial progress toward our goals of understanding the geochemistry of $\mathrm{Cu}$ in alteration processes and the broader aspects of silicate alteration in the hydrothermal systems of porphyry copper deposits. While we now have explored samples from a wide enough range of deposits to state conclusively that anomalous $\mathrm{Cu}$ in the sheet silicates is introduced during weathering and is primarily not in solid solution, we still have much work to do in understanding the geochemical systematics of these types of alteration, not to mention preparing the results for publication. The three major thrusts for the second year of this project will be to (1) complete observations on the Cyprus Casa Grande sheet silicates and also explore the feldspar reactions; (2) perform additional experiments and study the run products with TEM, in order to constrain the possible reactions; and (3) perform the TEM work on a much wider range of the Bingham Canyon rocks, so that we can achieve a more complete picture of the alteration reactions in this large hydrothermal system. Details are given below,

\section{Cyprus Casa Grande Studies}

We will extend our observations to include more samples, including samples from the unexamined brochantite and chalcocite zones. This will provide a complete data set on the mode of incorporation of $\mathrm{Cu}$ into sheet silicates throughout the weathering column. In addition, we have yet to make detailed observations on hydrothermal alteration and weathering reactions in the feldspars (plagioclase), pyroxenes, and amphiboles at Cyprus Casa Grande, which are necessary for more complete modeling of the hydrothermal and weathering events. From initial examination of thin sections, we note that the supergene alteration produced $\mathrm{Cu}$-enrichment textures such as chrysocolla intergrowths with 
plagioclase and brochantite intergrowths with biotite, and full characterization of such features will give a complete view of the lower-temperature alteration.

Our final plans are to report our observations on the behavior of $\mathrm{Cu}$, biotite, and other silicates during the supergene alteration as a separate journal article. Observations on the hydrothermal phase of alteration will probably be reported in combination with those from the Bingham Canyon deposit.

\section{Experimental Studies}

Now that we have demonstrated the feasibility of experimentally reacting biotite with $\mathrm{Cu}$-bearing solutions at low temperatures and on a reasonable laboratory time scale, we plan to extend the experiments to clarify the chemistry of this process. We intend to measure surface areas and to monitor both the fluid and solid compositions while varying $\mathrm{pH}, \mathrm{Cu}$ concentration in the fluid, $\mathrm{Eh}, \mathrm{K} / \mathrm{H}$ ratio, and temperature, in order to extract kinetic data and delineate the limits of external conditions for $\mathrm{Cu}$ sorption and the formation of $\mathrm{Cu}$ inclusions; as before, the experimental run products will be characterized with TEM methods to determine what reactions have occurred and their extent. These experiments will be continued with the Bancroft biotite.

In addition, we plan a few exploratory experiments to assess the internal constraints on Cu uptake and inclusion formation in biotite (i.e., how the chemistry of the biotite itself controls the process). We will attempt the reaction with Fe-free phlogopite, to test the hypothesis that a redox reaction involving octahedral $\mathrm{Fe}^{2+}$ is responsible for the formation of metallic inclusions in sheet silicates (see above). It this hypothesis is correct, we should observe the alteration of phlogopite to mica with some expanded, Cu-bearing interlayers, but there should be no precipitation of metallic $\mathrm{Cu}$. Along the same lines, we will perform the experiments with pre-oxidized, Fe-bearing biotite. Similarly, we plan to alter chlorite 
experimentally with $\mathrm{CuSO}_{4}$ solutions, in order to see if we can duplicate the natural textures and thus clarify the conditions of the chlorite reactions in nature. Again, the products from the flow-through experiments will be characterized using TEM methods, since the expanded interlayers, $\mathrm{Cu}$ inclusions, and chemistry of regions 10's of $\mathrm{nm}$ in diameter cannot be observed with any other technique.

We intend to report the results of these experiments in a separate journal article, which we will begin to prepare shortly.

\section{Bingham Canyon Studies}

As noted in the progress report and Table 3, we have made preliminary progress in determining the submicroscopic mechanisms of reaction and their detailed chemistry, but we have much work to do. We have 34 samples from the study of Bowman et al. 1987, covering all the major zones of hydrothermal alteration, and we intend to investigate the reactions in the mafic minerals and feldspars of all of them. Assuming that we are successful at determining the operative reaction mechanisms from HRTEM work, we will use the mechanisms to calculate exact reactions using the formalism of Veblen and Ferry (1983), as indicated in our original proposal. This should lead to a much better understanding of the mass balances between rock and hydrothermal fluid at different stages in the alteration history.

We plan to report the results of the Bingham Canyon portion of this study in a major journal publication, possibly combined with the hydrothermal alteration portion of the Cyprus Casa Grande work. 


\section{REFERENCES}

Aden, G. D., and Buseck, P. R. (1979) Rapid quantitative analysis of individual particles by energy dispersive spectrometry. In D. Newberry, Ed., Microbeam analysis, pp. 254-258. San Francisco Press, San Francisco.

Banfield, J. F., and Eggleton, R. A. (1988) Transmission electron microscope study of biotite weathering. Clays and Clay Minerals, 36, 47-60.

Beane, R. E., and Titley, S. R. (1981) Porphyry copper deposits part II. Hydrothermal alteration and mineralization. In B. J. Skinner, Ed., Economic Geology 75th Anniversary Volume, pp. 235-269.

Bowman, J. R., Parry, W. T., Kropp, W. P., and Kruer, S. A. (1987) Chemical and isotopic evolution of hydrothermal solutions at Bingham, Utah. Economic Geology, $82,395-428$.

Cliff, G., and Lorimer, G. W. (1975) The quantitative analysis of thin specimens. Journal of Microscopy, 103, 203-207.

Cook, S. S. (1988) Supergene copper mineralization at the Lakeshore Mine, Pinal County, Arizona. Economic Geology, 83, 297-309.

Earley, D., III, Iton, E. S., Morozas, D., and Veblen, D. R. (1990) Experimental weathering of biotite with $\mathrm{CuSO}_{4}$ solutions: Some preliminary results and TEM observations. Geological Society of America Abstracts with Programs, 22, to be submitted.

Hendry, D. A. F., Chivas, A. R., Long, J. V. P., and Reed, S. J. B. (1985) Chemical differences between minerals from mineralizing and barren intrusions from some North American porphyry copper deposits. Contributions to Mineralogy and Petrology, 89, 317-329.

Hendry, D. A. F., Chivas, A. R., Reed, S. J. B., and Long, J. V. P. (1981) Geochemical evidence for magmatic fluids in porphyry copper mineralization. II. Ion probe analysis of $\mathrm{Cu}$ contents of mafic minerals, Koloula igneous complex. Contributions to Mineralogy and Petrology, 78, 404-412.

Ilton, E. S., and Veblen, D. R. (1988) Copper inclusions in sheet silicates from porphyry $\mathrm{Cu}$ deposits. Nature, 516-518.

Ilton, E. S., and Veblen, D. R. (1990) The origin and mode of Cu enrichment in biotites from porphyry Cu environments: a TEM study. Geological Society of America Abstracts with Programs, 22, to be submitted.

Livi, K. J. T. (1987) Geothermometry of exsolved augites from the Laramie Anorthosite Complex, Wyoming. Contributions to Mineralogy and Petrology, 96, 371-380. 
Livi, K. J. T., and Veblen, D. R. (1987) "Eastonite" from Easton, Pennsylvania: A mixture of phlogopite and a new form of serpentine. American Mineralogist, 72, 113-125.

Myklebust, R. L., Fiori, C. E., and Heinrich, K. F. J. (1978) FRAMEC: A compact procedure for quantitative energy-dispersive electron probe $\mathrm{X}$-ray analysis. National Bureau of Standards Technical Memorandum.

Page, R. H., and Wenk, H.-R. (1979) Phyllosilicate alteration of plagioclase studied by transmission clectron microscopy. Geology, 7, 393-397.

Titley, S. R. (1988) Silicates flushed with copper. Nature, 334, 472-473.

Veblen, D. R., and Bish, D. L. (1988) TEM and X-ray study of orthopyroxene megacrysts: Microstructures and crystal chemistry. American Mineralogist, 73, $677-691$.

Veblen, D. R., and Ferry, J. M. (1983) A TEM study of the biotite-chlorite reaction and comparison with petrologic observations. American Mineralogist, 68, 1160-1168.

Zaluzek, N. J. (1984) A beginner's guide to X-ray analysis in an analytical electron microscope: Part 1--Quantification K-factor and $\mathrm{Si}(\mathrm{Li})$ detector calculations. Electron Microscopy Society of America Bulletin, 14, 67-75. 


\section{APPENDIX I: \\ COPY OF ILtON AND VEblen (1988), FOR COMPARISON WITH FIGURE 5}

